\title{
THE RESTORATION OF THE REFORMED CHURCH OF AITON 2018-2020 CASE STUDY, CONDITION SURVEY BY FACILITY CONDITION INDEX
}

\author{
Dr. Márton István Bulbuk ${ }^{*}$ 四 \\ ${ }^{* 1}$ Civil Engineer, Conservation Engineer, Conins Ltd, Miercurea-Ciuc, Romania
}

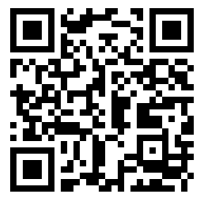

DOI: https://doi.org/10.29121/ijetmr.v7.i6.2020.695

Article Citation: Dr. Márton István Bulbuk. (2020). THE RESTORATION OF THE REFORMED CHURCH OF AITON 2018-2020 CASE STUDY, CONDITION SURVEY BY FACILITY CONDITION INDEX. International Journal of Engineering Technologies and Management Research, 7(6), 102-116. https://doi.org/10.29121/ijetmr.v7 i6.2020.695

Published Date: 20 June 2020

Keywords:

Technical Condition Survey

Condition Index

Structural Damage

Reinforcement

Restoration

\section{ABSTRACT}

The professional restoration of an initially Catholic, and then, after an 18th-century reconstruction, Reformed, single-tower church of medieval origin, having mixed walls and an eclectic roof structure, following two consecutive, incorrect interventions.

The technical condition of listed buildings is the indicator of their general structural condition. To assess errors and damage, I have compiled a new method that includes a sample to follow, as well as damage assessment tables, recommended procedures, and calculations. This calculation method shows the structural condition of listed buildings and the value of the approximate restoration costs. I present this procedure through the presently ongoing survey and restoration process of a listed building in Aiton, near Cluj-Napoca, Transylvania.

\section{INTRODUCTION}

\subsection{HISTORY OF THE CHURCH}

The first documented mention of Aiton, a settlement next to Cluj-Napoca, was in 1320 and 1323, as Ohthunth de Comitatu de Kulus, listed as a church settlement. Owned, in the $15^{\text {th }}$ century, by gentry families, then later, from the $18^{\text {th }}$ century onwards, by the Zeyk, Kemény, Tisza and Bethlen families. The church is listed as a national monument, under number CJ-II-m-B-07515. From the original Catholic church, the Romanesque doorway and a detail of the coffered ceiling, made in 1795, on a dark green background with floral patterns, have survived. The original doorway, and the remaining form of the sanctuary, dated by archaeologists to the $14^{\text {th }}$ century, then the present surviving condition denotes the end of the $17^{\text {th }}$, the beginning of the $18^{\text {th }}$ century. The floor plan of the church also suggests that it was originally used by the Catholic community and later transformed into a Reformed church due to the age of the Reformation and the Protestant religion of the aforementioned families. In place of the sanctuary, a gallery is erected with a small pump organ, which was later equipped with electric bellows. During the present renovation, the wooden gallery and organ built on the site of the sanctuary will be restored with the help of famous wood restorers from Transylvania. The last famous families of the settlement are the Tisza family of Ineu,

(C) 2020 The Author(s). This is an open access article distributed under the terms of the Creative Commons Attribution License, which permits unrestricted use, distribution, and reproduction in any medium, provided the original author and source are credited. 
the Zeyk family of Zeyk, and the Sándor family of Csíkszentmihály (Mihăileni). The latter are descendants of the Székelyrabonbans. This is also confirmed by a chalice considered sacred by them. The Sándor family has a mansion in Aiton to this day. The current restoration and complete renovation is the result of the attitude of the locals, the enthusiasm of the devout community.
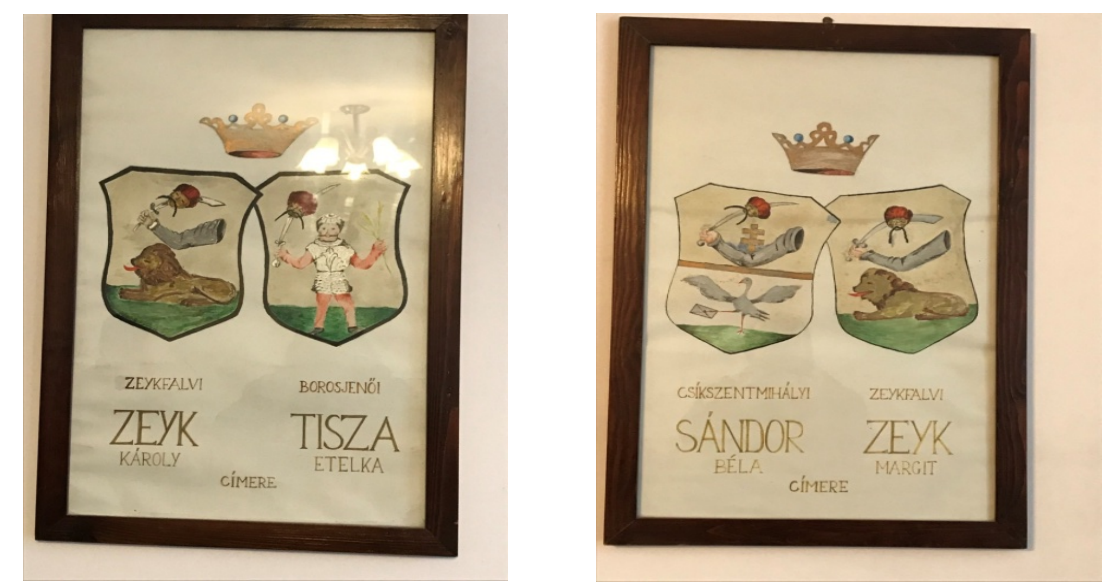

Figure 1: Marriage coats of arms of noble families on the church wall

The church visible today stands on the original, $14^{\text {th }}$-century foundations in a $19^{\text {th }}$-century neo-Gothic form, having burned down and re-erected several times throughout the ages. It underwent two unprofessional

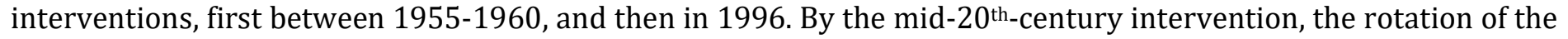
southern wall had already been noticed, which they wanted to stop by installing reinforced concrete buttresses. However, these, sitting on foundations laid to inadequate depth (not on the same level as the foundations of the church), rotated and broke away from the wall and the south-west corner of the church, due to the differentiated foundation, tearing out entire pieces of wall and masonry construction. Thus, instead of a support force, pulling forces were brought into the southern church wall. This pulling force was exacerbated to an even greater extent by the multiple swelling and shrinkage of the wet clayey soil under the foundations of the buttresses, as a result of the rainwater discharged here.

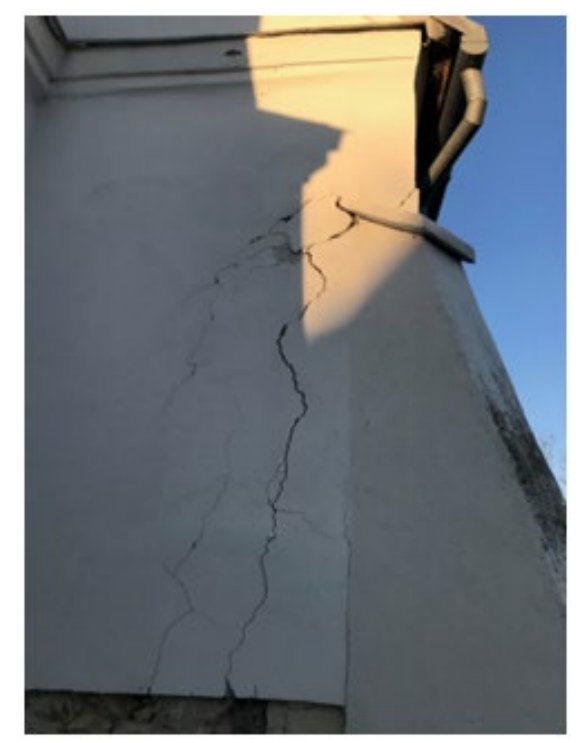

Figure 2: Structural crack in the wall caused by the subsidence of the base of the pillar due to the wet, clayey soil

The survival of the southern wall is due to a pair of metal anchors running along the vault and gallery of the inner balcony, as well as owing to the walls of the side entrance and the semicircular masonry of the old sanctuary. 


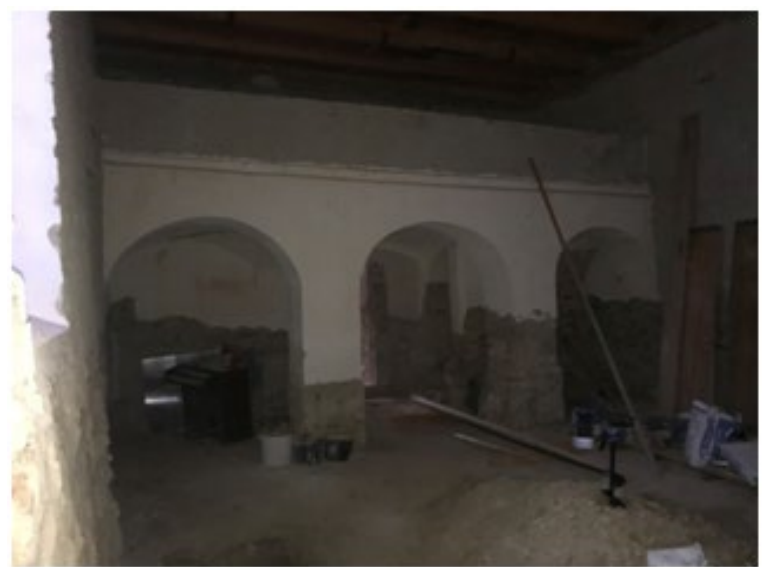

Figure 3: Western choir vault ring beam with double metal bracing

In 1996, the already cracked north wall was reinforced, by chasing out the section above the foundations around the building and installing a reinforced concrete ring beam, as well as applying a layer of cement mortar cladding reinforced with a welded iron mesh to the full height of the wall above it. Thus, with this, the soil moisture was absorbed in an even higher proportion and height in the already partially soaked walls, and the material quality and load-bearing role of the northern and eastern walls were compromised.
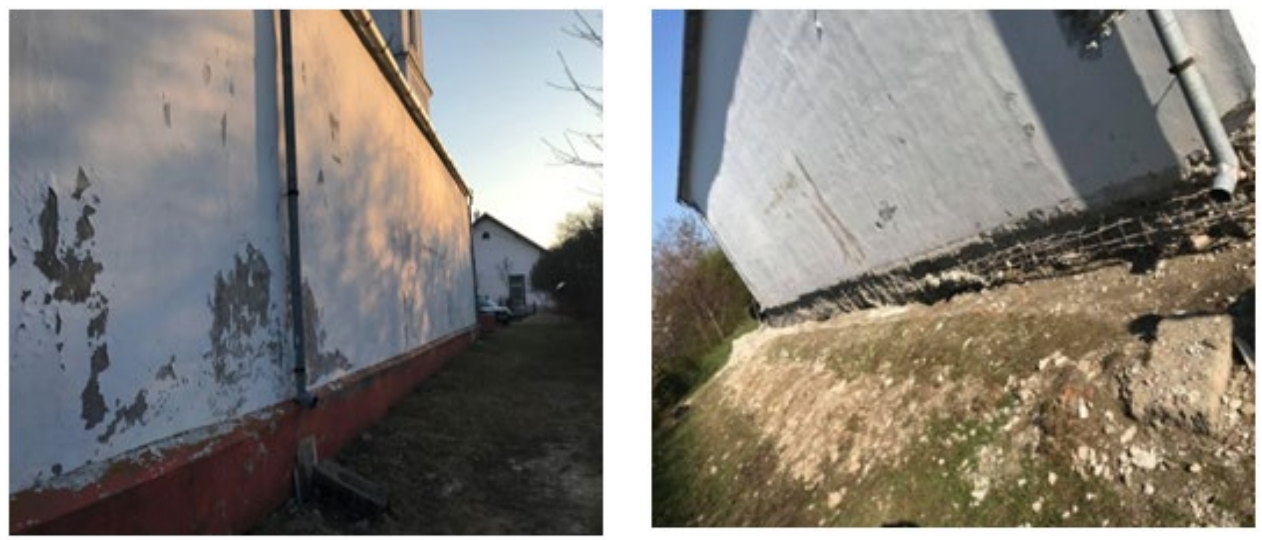

Figure 4: Absorption of moisture in the walls as a result of cement mortar and steel mesh reinforced concrete cladding

In addition, reinforced concrete sidewalks were poured around the building, and a concrete strip was poured by the walls in the interior to secure the footing and bricks. By doing so, they prevented the walls from being ventilated above the foundations in the absence of horizontal insulation.
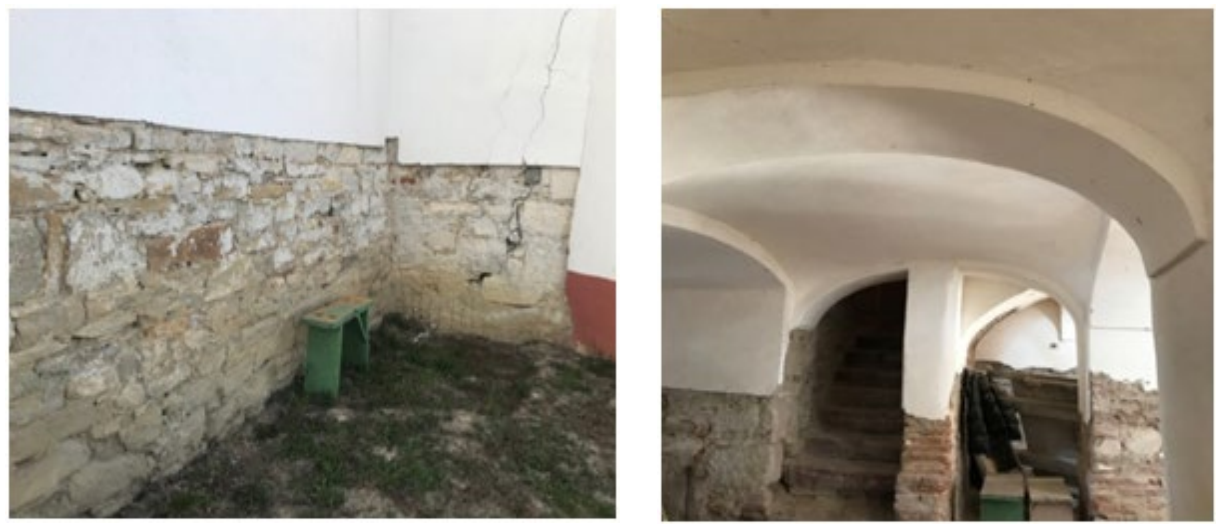

Figure 5: Soaked stone walls and dry-stone walls, 2 years after the removal of rendering 
Dr. Márton István Bulbuk

On-site inspection conducted in 2018 by the designers (Moebius Engineering Ltd., Cluj-Napoca) drew attention also to the biochemical damage that affected the wood of the roof structure, and, which stated that $80-90 \%$ of the wood structure got damaged by fungi and its components were severely rotten; the rafter is unreliable in terms of strength. It is recommended to replace the roof completely, to include the roof covering and tinsmith work.

\section{ASSESS AND DETERMINE THE CONDITION OF THE BUILDING}

I propose a method that I myself have developed and used several times to fully assess and determine the condition of the building. I developed this method in my doctoral dissertation defended in 2011, which gives the extent of damage to the listed building in a final condition evaluation table and determines the appropriate interventions based on the calculated values. The calculation is based on decades of construction experience.

The method is the following:

Let us first review the characteristic damages of mixed, stone and brick-walled, wooden-roofed listed buildings, on the basis of which we inspect the building:

- Planning deficiencies / subsequent incorrect interventions (loading, repairs).

- Lack of horizontal wall ties, damage to old wood or metal anchors.

- Uneven settling of foundations as a result of groundwater, soaking, landslip.

- Chemical and biological damage to wall components.

- Biochemical or fire / water damage to wooden roof structures.

- Cracking, water seepage, deflection of masonry slabs, loss of elements.

- Moisture or biochemical damage to wooden floor constructions, coffered ceilings.

Let us now list the professional reinforcement interventions:

- Installation of metal anchors or tensioning straps, replacement of old elements.

- Installation and casting of reinforced concrete ring beams.

- Under-casting, masonry, soil improvements.

- Claddings (footings, walls, floor structures).

- Reconstruction of stone and brick slabs.

- Installation of "Brutt Saver" spiral metal wires.

- Substitution, replacement, reinforcement of wooden roof elements.

- In case of major damage, complete roof replacement.

- Reinforcement of floor structures with professional interventions.

- Replacement and supplementation of the elements of wooden floor structures and coffered ceilings.

- Intricate, complex interventions.

Determining the extent of damage by calculating the facility condition index (in the case of 1-4-storey historic buildings).

\section{Determining the extent of damage by calculating a quality index:}

$$
\mathrm{Ci}=10-\mathrm{Di}(1)
$$

Where ' $\mathrm{Di}$ ' is the tabular scoring value, ' $\mathrm{Ci}$ ' is the type of damage, and 10 is the maximum score which determines a perfectly good structural condition that existed at the time of handover. ' $\mathrm{D}$ ' represents the score given from 1 to 10, based on the damage experienced. These values are given in the following tables, compiled for each subunit, based on the extent of any possible damage. At the same time ' $i$ ' shows the enumerated parameter and the type of damage.

Brick or stone masonry structures consist of the following five subunits:

1 Foundations, 2 Load-bearing walls, 3 Floor structures, 4 Roof structures, 5 Secondary subunits.

The scoring method and value of the degree of defects and damage (D) in the structure of brick and stone walls are included in the catalogue compiled for the said five subunits.

The catalogues identify the most common errors and suggest appropriate intervention procedures. 
The Restoration of The Reformed Church of Aiton 2018-2020 Case Study, Condition Survey by Facility Condition Index

Table 1: Catalogues of common errors and suggest

Table 1.1: Foundations

\begin{tabular}{|c|c|c|c|}
\hline Nr. & Name of damage & $\mathrm{D}$ & Proposed interventions \\
\hline 1.1 & $\begin{array}{l}\text { Settling foundations, rotations due to } \\
\text { inadequate foundation depths relative to } \\
\text { soil quality. }\end{array}$ & $\begin{array}{l}6- \\
8\end{array}$ & $\begin{array}{l}\text { Geotechnical survey. Under-casting, under-masonry, } \\
\text { possible sheathing, injections to improve the soil. }\end{array}$ \\
\hline 1.2 & $\begin{array}{l}\text { Settlings caused by differentiated } \\
\text { foundations of different depths (in case } \\
\text { of partial basements or subsequently } \\
\text { built parts of the building, extensions). }\end{array}$ & $\begin{array}{l}4- \\
8\end{array}$ & $\begin{array}{l}\text { Partial under-casting to even out foundations. } \\
\text { Strengthening of settled walls. }\end{array}$ \\
\hline 1.3 & $\begin{array}{l}\text { Water seepage under the foundations, } \\
\text { settling caused by floods, cracking in the } \\
\text { foundations. }\end{array}$ & $\begin{array}{c}3- \\
6\end{array}$ & $\begin{array}{l}\text { Elimination of causes. Under-casting or reinforcements } \\
\text { made by sheathing. }\end{array}$ \\
\hline 1.4 & $\begin{array}{l}\text { Rotations and cracks caused by soil } \\
\text { pressure. }\end{array}$ & $\begin{array}{c}3- \\
9\end{array}$ & $\begin{array}{l}\text { Stabilisation and fixing of batters and sloped terrain. } \\
\text { Strengthening of foundations. Partial or complete } \\
\text { demolition of the building, part of a building. }\end{array}$ \\
\hline 1.5 & $\begin{array}{l}\text { Depressions and settlings caused by } \\
\text { material damage (stone, brick, bonding } \\
\text { mortar). } \\
\text { - general } \\
\text { - } \text { partial. }\end{array}$ & $\begin{array}{l}5- \\
8 \\
3- \\
5\end{array}$ & $\begin{array}{l}\text { Sheathing and reinforcement, possibly by under-casting. } \\
\text { Material replacement repairs, proper mortar injections, } \\
\text { etc. }\end{array}$ \\
\hline 1.6 & $\begin{array}{l}\text { Local damage (settlings, cracks, etc.) } \\
\text { caused by battered gutters or drains, } \\
\text { plant roots, or by accidents. }\end{array}$ & $\begin{array}{l}2- \\
5\end{array}$ & $\begin{array}{l}\text { Exclusion of causes. } \\
\text { Local repairs or reinforcements. }\end{array}$ \\
\hline 1.7 & $\begin{array}{l}\text { Cracks and structural deficiencies } \\
\text { appearing in basement walls, loss of } \\
\text { elements, elements of basement wall } \\
\text { detaching, coming loose. }\end{array}$ & $\begin{array}{l}4- \\
8\end{array}$ & $\begin{array}{c}\text { Cutting, chiselling of brick or stone strips. } \\
\text { Replacement and supplementation of elements and } \\
\text { materials of appropriate quality (from demolition or with } \\
\text { new similar materials). }\end{array}$ \\
\hline 1.8 & $\begin{array}{l}\text { Levelling or filling damp, wet basements } \\
\text { with soil or materials left over from } \\
\text { demolition to support the walls, or in } \\
\text { hope to displace water as a result of } \\
\text { improper and unprofessional } \\
\text { interventions. }\end{array}$ & $\begin{array}{l}4- \\
8\end{array}$ & $\begin{array}{l}\text { Removal of fill material. Drying basements subsequent to } \\
\text { exploration and elimination of causes of water seepage. } \\
\text { Carry out the necessary reinforcements to repair the } \\
\text { damage. }\end{array}$ \\
\hline 1.9 & $\begin{array}{l}\text { Unprofessional, bituminous, pool-type } \\
\text { basement insulation, in the hope of } \\
\text { displacing the groundwater seepage, } \\
\text { subsequent to improper, previous repair } \\
\text { interventions. }\end{array}$ & $\begin{array}{l}4- \\
6\end{array}$ & $\begin{array}{l}\text { Elimination of water seepage possibilities, with correct, } \\
\text { professional procedures, drainage, external wall } \\
\text { insulation. Removal of internal insulation, assurance of } \\
\text { drying of walls and floors, original walking surfaces. } \\
\text { Possible material replacement, reinforcements, } \\
\text { restorations after removal of damaged elements. }\end{array}$ \\
\hline
\end{tabular}

Table 2: Subsection of Load-Bearing Walls

\begin{tabular}{|l|l|l|l|}
\hline 2.1 & $\begin{array}{l}\text { Crumbled bricks, structural deficiencies, fallen } \\
\text { out pieces of wall remaining after detached } \\
\text { rendering. According to their size } \\
\text { - less than } 10 \%\end{array}$ & $\begin{array}{l}\text { - more than } 10 \% \\
\text { of the cross section of the walls. }\end{array}$ & $\begin{array}{l}\text { Local repairs by replacing lost elements. } \\
\text { the degree of damage. }\end{array}$ \\
\hline 2.2 & $\begin{array}{l}\text { Mould at the foot of the wall due to lack of or } \\
\text { damage to horizontal foundation insulation. }\end{array}$ & $3-5$ & $\begin{array}{l}\text { Repairs after cleaning walls, removal of rendering. } \\
\text { Drying of the walls, replacement of the broken }\end{array}$ \\
\hline
\end{tabular}




\begin{tabular}{|c|c|c|c|}
\hline & & & $\begin{array}{l}\text { elements, followed by restoration of the horizontal } \\
\text { insulation by injection, replacement of the } \\
\text { bituminous foil after wall slitting, or insertion of a } \\
\text { stainless-steel sheet. }\end{array}$ \\
\hline 2.3 & $\begin{array}{l}\text { Local cracks in the walls due to the settling of } \\
\text { the foundations } \\
\text { - for walls of normal thickness } \\
(25-50 \mathrm{~cm}) \\
\text { - for thick walls }(>50 \mathrm{~cm}) \text {. }\end{array}$ & $2-5$ & $\begin{array}{l}\text { Wall demolitions at the site of damage, and } \\
\text { reconstruction of walls tracing the old masonry } \\
\text { construction, connecting the rows of bricks with } \\
\text { the original masonry construction. } \\
\text { To make a new masonry construction on the } \\
\text { external, visible parts of the walls, professionally } \\
\text { combining the old and new masonry, then to fill the } \\
\text { internal cracks by injection. }\end{array}$ \\
\hline 2.4 & $\begin{array}{l}\text { Larger, wider cracks, fractures in the walls, } \\
\text { settling and rotation of the foundations, due to } \\
\text { lack of horizontal ties (metal bracing, ring } \\
\text { beams). }\end{array}$ & $4-8$ & $\begin{array}{l}\text { Reinforced concrete cladding strengthening, metal } \\
\text { bracing, after installation of reinforced concrete } \\
\text { ring beams and columns, injection of cracks or } \\
\text { reconstruction of walls. }\end{array}$ \\
\hline 2.5 & $\begin{array}{l}\text { Appearance of local cracks at the corners of } \\
\text { walls, at the junction of longitudinal and } \\
\text { transverse walls, as a result of horizontal loads } \\
\text { (earthquakes, seismic movements). }\end{array}$ & $3-6$ & $\begin{array}{l}\text { Insertion of reinforced concrete or ring beams with } \\
\text { metal bracing, injections after insertion of } \\
\text { pilasters, buttresses, zonal reconstruction of walls } \\
\text { or cladding restorations. }\end{array}$ \\
\hline 2.6 & $\begin{array}{l}\text { Damage to the walls of the top floor of timber } \\
\text { joist floored buildings, due to the lack of } \\
\text { horizontal wood, metal or reinforced concrete } \\
\text { ring beams. }\end{array}$ & $3-8$ & $\begin{array}{l}\text { Installation of metal or reinforced concrete ring } \\
\text { beams at the level of wooden joist floors, if } \\
\text { possible. Possible wooden joist replacement with } \\
\text { reinforced concrete slabs or metal joists. } \\
\text { Restoration of masonry constructions. }\end{array}$ \\
\hline 2.7 & $\begin{array}{l}\text { Incorrect walling up of original openings and } \\
\text { doors without subsequent wall ties, due to the } \\
\text { lack of ties between the old and the new wall. }\end{array}$ & $4-6$ & $\begin{array}{l}\text { Demolition of new walls, butting the two walls into } \\
\text { each other, interconnecting them professionally } \\
\text { with suitable, similar materials. }\end{array}$ \\
\hline 2.8 & $\begin{array}{l}\text { Falling and tilting of wall parts, appearance of } \\
\text { larger cracks, subsequent, incorrect } \\
\text { interventions, as a result of using inadequate } \\
\text { (of incorrect size, shape and different material) } \\
\text { material. }\end{array}$ & $4-8$ & $\begin{array}{l}\text { Demolition and reconstruction of walls with } \\
\text { professional materials, installation of possible } \\
\text { reinforcements. }\end{array}$ \\
\hline 2.9 & $\begin{array}{l}\text { Larger cracks and walls shifted out of place, } \\
\text { rotation of entire wall sections, as a result of } \\
\text { previous unprofessional restoration } \\
\text { interventions. Placement and installation of } \\
\text { alien, unsuitable structures or materials in } \\
\text { parts of buildings, during previous } \\
\text { interventions. }\end{array}$ & $4-8$ & $\begin{array}{l}\text { Reinforcements, under-casting, injections at the } \\
\text { foundation level. Complete removal of alien, } \\
\text { unsuitable elements and structures, and replacing } \\
\text { them by using appropriate, professional methods. }\end{array}$ \\
\hline 2.10 & $\begin{array}{l}\text { Exterior and interior surface damage to walls } \\
\text { due to smoke, soot and contaminating deposits. }\end{array}$ & $6-8$ & $\begin{array}{l}\text { Removal of damage by various professional } \\
\text { procedures. Restoration of wall surfaces, } \\
\text { subsequent protection. }\end{array}$ \\
\hline 2.11 & $\begin{array}{l}\text { Violent, malicious damage done to exterior and } \\
\text { interior wall surfaces. }\end{array}$ & $4-8$ & $\begin{array}{l}\text { Surface cleaning with high pressure water, air jet, } \\
\text { possible chemical treatment. Repair restoration. }\end{array}$ \\
\hline
\end{tabular}


The Restoration of The Reformed Church of Aiton 2018-2020 Case Study, Condition Survey by Facility Condition Index

2.12 Damage to wall decorations, stuccoes, frames, $6-8$ sculptures, murals, etc.

Eliminating the cause of damage. Professional repairs, restorations. Installation of protective elements, application of coatings.

Table 3: Subsection of Floor Structures

\begin{tabular}{|c|c|c|c|}
\hline 3.1 & \multicolumn{3}{|l|}{ Brick vaults } \\
\hline 3.1 .1 & $\begin{array}{l}\text { Surface fracture of vaults due to } \\
\text { rotation of } \\
\text { countermure. }\end{array}$ & $3-7$ & $\begin{array}{l}\text { Fixing, reinforcing abutments with binding metal bracing, } \\
\text { metal wires or reinforced concrete ring beams, wedging } \\
\text { or injection of cracks, or partial vault reconstruction. }\end{array}$ \\
\hline 3.1 .2 & $\begin{array}{l}\text { Larger cracks in the vault due to } \\
\text { horizontal or vertical movement of } \\
\text { retaining walls. }\end{array}$ & $5-8$ & $\begin{array}{l}\text { Reinforcement and fixing of load-bearing walls, wedging } \\
\text { of cracks, and reinforcement of external or internal } \\
\text { surfaces by means of cladding, depending on their } \\
\text { condition. }\end{array}$ \\
\hline 3.1 .3 & $\begin{array}{l}\text { Cracks and openings in the vault due to } \\
\text { loads installed over time, exceeding the } \\
\text { later load capacity. }\end{array}$ & $2-6$ & $\begin{array}{l}\text { Removing overloads. Restoration and reconstruction of } \\
\text { the vault. Installation of possible new metal joists or } \\
\text { reinforced concrete slabs as a function of increasing the } \\
\text { imposed load. }\end{array}$ \\
\hline 3.1 .4 & $\begin{array}{l}\text { Damage to the vault, water seepage as a } \\
\text { result of damaged building engineering } \\
\text { or poorer material quality, due to } \\
\text { possible aging of the constituent } \\
\text { materials, etc. }\end{array}$ & $3-8$ & $\begin{array}{l}\text { Replacement of elements, bricks, stones, reinforcement } \\
\text { by cladding, possible vault reconstruction. }\end{array}$ \\
\hline 3.1 .5 & $\begin{array}{l}\text { Damage caused by subsequent, } \\
\text { incorrectly fitted countermures and } \\
\text { supports installed under the vaults. }\end{array}$ & $4-8$ & $\begin{array}{l}\text { Subsequent removal of inappropriate countermures and } \\
\text { professional restoration, vault reinforcement. }\end{array}$ \\
\hline 3.1 .6 & $\begin{array}{l}\text { Damage caused by improper drilling, } \\
\text { and as a result of making larger } \\
\text { openings (cracks, crumbling wall). }\end{array}$ & $4-8$ & $\begin{array}{l}\text { Partial dismantling of the vault, vault reconstruction } \\
\text { subsequent to professional framing of openings. }\end{array}$ \\
\hline 3.1 .7 & $\begin{array}{l}\text { Deflection and flattening of vault, due } \\
\text { to local, zonal overload. }\end{array}$ & $4-6$ & $\begin{array}{l}\text { Removal of overloads if possible, and carrying out } \\
\text { subsequent reinforcements, possible zonal or complete } \\
\text { vault reconstruction. }\end{array}$ \\
\hline 3.2 & Metal-ribbed, Prussian vaults & & \\
\hline 3.2 .1 & $\begin{array}{l}\text { Corrosion and rusting of supporting } \\
\text { metal ribs, relative to the cross section } \\
\text { of the rib }\end{array}$ & $2-3$ & Rust removal, anti-corrosion treatment. \\
\hline & - below $10 \%$ & $3-8$ & $\begin{array}{l}\text { Depending on the degree of damage, reinforcement or rib } \\
\text { replacement. }\end{array}$ \\
\hline & - above $10 \%$. & & \\
\hline 3.2 .2 & $\begin{array}{l}\text { Alteration and deformation of roof } \\
\text { structure above allowance, due to } \\
\text { overloads. }\end{array}$ & $3-6$ & $\begin{array}{l}\text { Overload removal and subsequent professional } \\
\text { strengthening by inserting new struts. }\end{array}$ \\
\hline 3.2 .3 & $\begin{array}{l}\text { Cracks, missing elements of the } \\
\text { masonry construction as a result of } \\
\text { damage and aging of constituent } \\
\text { materials, due to various causes. }\end{array}$ & $4-7$ & $\begin{array}{l}\text { Replacement of or addition to elements, materials, } \\
\text { implementation of wedges or injections, partial or } \\
\text { complete vault reconstruction. }\end{array}$ \\
\hline 3.3 & Timber joist floors & & \\
\hline 3.3 .1 & $\begin{array}{l}\text { Anaerobic fungal infection in the beams } \\
\text { of the timber joist floor and subfloors. }\end{array}$ & $7-9$ & $\begin{array}{l}\text { Dismantling of timber joist floor and its partial or } \\
\text { complete replacement, depending on the extent of } \\
\text { infection. }\end{array}$ \\
\hline
\end{tabular}


Dr. Márton István Bulbuk

\begin{tabular}{|c|c|c|c|}
\hline 3.3 .2 & $\begin{array}{l}\text { Rotting of the ends of floor joists at } \\
\text { supports. }\end{array}$ & $4-8$ & $\begin{array}{l}\text { Elimination of damage, cut-outs, additions or } \\
\text { replacement of joists. }\end{array}$ \\
\hline 3.3 .3 & $\begin{array}{l}\text { Floor structure alteration and } \\
\text { deformation above allowance, due to } \\
\text { overloads. }\end{array}$ & $3-6$ & $\begin{array}{l}\text { Overload removal, timber joist floor replacement, by } \\
\text { lifting if possible (depending on material dryness value) } \\
\text { and reinforcement, possible substitution of material. }\end{array}$ \\
\hline 3.3 .4 & $\begin{array}{l}\text { The timber joist floor no longer } \\
\text { provides horizontal rigidity relative to } \\
\text { the walls; it does not provide adequate } \\
\text { horizontal force transmission to the } \\
\text { load-bearing walls. }\end{array}$ & $4-7$ & $\begin{array}{l}\text { Strengthening of timber joist floor, professional } \\
\text { placement of additional roof structure, substitution of } \\
\text { material, possible timber joist floor replacement by using } \\
\text { the most appropriate, most suitable materials, perhaps } \\
\text { metal or reinforced concrete, by observing the floor } \\
\text { levels. }\end{array}$ \\
\hline \multicolumn{4}{|c|}{ 3.4 Reinforced concrete slabs } \\
\hline 3.4 .1 & $\begin{array}{l}\text { Crumbling of concrete in the } \\
\text { compressed part of the slab. }\end{array}$ & $6-8$ & Local or general reinforcement depending on size. \\
\hline \multirow[t]{3}{*}{3.4 .2} & $\begin{array}{l}\text { Corrosion of reinforcing bars with } \\
\text { reduction of cross section, detachment } \\
\text { and disintegration of protective } \\
\text { concrete coating }\end{array}$ & $3-4$ & Local repairs, cleanings, additions to coatings. \\
\hline & $-\Phi<10 \%$ & $4-8$ & ents, required professional interventions. \\
\hline & $-\Phi>10 \%$ & & \\
\hline 3.4 .3 & $\begin{array}{l}\text { Damaged, porous concrete with the } \\
\text { appearance of segregated nests, } \\
\text { concrete carbonation, loss of gravel. }\end{array}$ & $2-5$ & $\begin{array}{l}\text { Depending on the depth and extent of damage, local } \\
\text { interventions, restorations, reinforcements. }\end{array}$ \\
\hline 3.4 .4 & $\begin{array}{l}\text { Corroded concrete with decreasing } \\
\text { cross section. }\end{array}$ & $4-8$ & $\begin{array}{l}\text { Local or general reinforcements depending on extent and } \\
\text { depth of involvement. In severe cases, complete } \\
\text { demolition and slab replacement. }\end{array}$ \\
\hline \multirow[t]{3}{*}{3.4 .5} & $\begin{array}{l}\text { Vertical and oblique cracks in the } \\
\text { girders }\end{array}$ & $1-3$ & Professional injection of cracks. \\
\hline & - crack opening $<0.3 \mathrm{~mm}$ & $4-8$ & Reinforcements, depending on condition. \\
\hline & - crack opening $>0.3 \mathrm{~mm}$. & & \\
\hline 3.4 .6 & $\begin{array}{l}\text { Seepage water, damage caused by } \\
\text { moisture, mould or condensation. }\end{array}$ & $1-2$ & $\begin{array}{l}\text { Removal of causes, biochemical treatments, proportional } \\
\text { restorations, repairs. }\end{array}$ \\
\hline \multirow[t]{2}{*}{3.4 .7} & $\begin{array}{l}\text { Deformations above permissible } \\
\text { values. }\end{array}$ & $4-5$ & $\begin{array}{l}\text { Professional reinforcements, possible replacement of } \\
\text { floor structure. }\end{array}$ \\
\hline & & & $\begin{array}{l}\text { Elimination of the cause of damage, professional } \\
\text { interventional reinforcements by cladding, with the } \\
\text { insertion of ribs. }\end{array}$ \\
\hline 3.4 .8 & $\begin{array}{l}\text { Damage to reinforced concrete domes } \\
\text { and vaults. }\end{array}$ & $4-5$ & \\
\hline
\end{tabular}

Table 4: Subsection of Timber Roof Structures

\begin{tabular}{|l|l|l|l|}
\hline 4.1 & $\begin{array}{l}\text { Damage, rotting, aging of trusses due } \\
\text { to lack of repair and maintenance } \\
\text { to a lesser extent } \\
\text { to a greater extent. }\end{array}$ & $\begin{array}{l}3- \\
5\end{array}$ & $\begin{array}{l}\text { Repairs, local strengthening. } \\
\text { Replacement of trusses, reinforcements. }\end{array}$ \\
\hline 4.2 & $\begin{array}{l}\text { Rotations, movement at intersections } \\
\text { as a result of undervalued loads, due to } \\
\text { design errors. }\end{array}$ & $\begin{array}{l}4- \\
6\end{array}$ & $\begin{array}{l}\text { Replacements, additions, reinforcements, repairs, pulling into } \\
\text { position, hoisting with the implementation of bracing and } \\
\text { trusses. }\end{array}$ \\
\hline
\end{tabular}


The Restoration of The Reformed Church of Aiton 2018-2020 Case Study, Condition Survey by Facility Condition Index

\begin{tabular}{|l|l|l|l|}
4.3 & $\begin{array}{l}\text { Fungal attacks, dry rot timber decay } \\
\text { caused by the spread of dry rot fungus. }\end{array}$ & $\begin{array}{l}2- \\
5\end{array}$ & $\begin{array}{l}\text { Cleaning based on the extent of spread. Reinforcements carried } \\
\text { out subsequent to material, roof element or complete roof } \\
\text { replacement, antifungal treatments. }\end{array}$
\end{tabular}

Table 5: Secondary Subsections

\begin{tabular}{|c|c|c|c|}
\hline 5.1 & $\begin{array}{l}\text { Cracking, tearing of partition walls due to lack of } \\
\text { foundations and / or lack of horizontal wall ties. }\end{array}$ & $2-6$ & Demolition, wall reconstruction. \\
\hline 5.2 & $\begin{array}{l}\text { Damage caused by incorrect condition of building } \\
\text { engineering (gutters, drains, various fittings). }\end{array}$ & $2-4$ & $\begin{array}{l}\text { Repairs, partial replacements, or complete } \\
\text { replacement of elements. }\end{array}$ \\
\hline 5.3 & $\begin{array}{l}\text { Displacement and warping of balcony mounting } \\
\text { brackets. }\end{array}$ & $3-8$ & $\begin{array}{l}\text { Professional reinforcements, replacements, } \\
\text { replacement of mounting brackets. }\end{array}$ \\
\hline 5.4 & Damage to the masonry of chimneys. & $2-5$ & $\begin{array}{l}\text { Partial demolition, replacement of } \\
\text { constituting elements, wall reconstruction. }\end{array}$ \\
\hline 5.5 & $\begin{array}{l}\text { Damage to various coverings (tile, metal, stone, reed, } \\
\text { glass). }\end{array}$ & $2-4$ & $\begin{array}{l}\text { Repairs, replacements, possible replacement } \\
\text { of the entire covering, depending on the } \\
\text { degree of damage. }\end{array}$ \\
\hline 5.6 & $\begin{array}{l}\text { Appearance of subsequent cracks in new partitions } \\
\text { placed on incorrect foundations (tiles, parquet, and } \\
\text { plastic floors) at the corner of the meeting of the floor } \\
\text { structure and the walls. }\end{array}$ & $3-6$ & $\begin{array}{l}\text { Wall demolition, dismantling and removal of } \\
\text { the floor underneath, followed by wall } \\
\text { reconstruction. }\end{array}$ \\
\hline 5.7 & $\begin{array}{l}\text { Cracks and torn off sections appearing at the corners } \\
\text { between the load-bearing walls and partitions, due to } \\
\text { the lack of suitable ties. }\end{array}$ & $3-4$ & $\begin{array}{l}\text { Demolition of partitions and appropriate } \\
\text { reconstruction of masonry construction. }\end{array}$ \\
\hline 5.8 & $\begin{array}{l}\text { Cracks appearing in the incorrect walling of openings } \\
\text { and doors, due to the insertion and retention of old } \\
\text { door-window frames. }\end{array}$ & $3-4$ & $\begin{array}{l}\text { After demolition of masonry and removal of } \\
\text { old frames, wall reconstruction by } \\
\text { professionally tying the old and new wall into } \\
\text { each other. }\end{array}$ \\
\hline 5.9 & $\begin{array}{l}\text { Damage to roof finials, towers, battlements, roof } \\
\text { parapets, weather strips. }\end{array}$ & $3-4$ & $\begin{array}{l}\text { Reinforcements, repairs, partial or complete } \\
\text { replacement, depending on the extent of } \\
\text { damage. }\end{array}$ \\
\hline
\end{tabular}

*Note: The tables are not exhaustive in terms of possible damage and can therefore be supplemented at a later stage.

Calculation of facility condition index for all building structural subunits (foundations, load-bearing walls, floor structures, roof structure, auxiliary structures)

$$
\text { Ist }=k \sum_{i=0}^{10} \mathrm{Ci}
$$

'Ist' quality index for a structural subunit (foundation, load-bearing walls, floor structures, roof structures, partitions, coverings, gutters, drains, building engineering, etc.). Coefficient ' $k$ ', in relation to duration, is given in the following table: 
Table 6: "K" values

\begin{tabular}{|l|l|l|l|l|l|l|l|}
\hline \multicolumn{7}{|c|}{ Time elapsed since construction or last restoration, in years } \\
\hline year & $0-10$ & $10-30$ & $30-50$ & $50-70$ & $70-90$ & $90-100$ & $>100$ \\
\hline k & 1 & $1-0.98$ & $0.98-0.93$ & $0.93-0.85$ & $0.85-0.70$ & $0.70-0.60$ & 0.50 \\
\hline
\end{tabular}

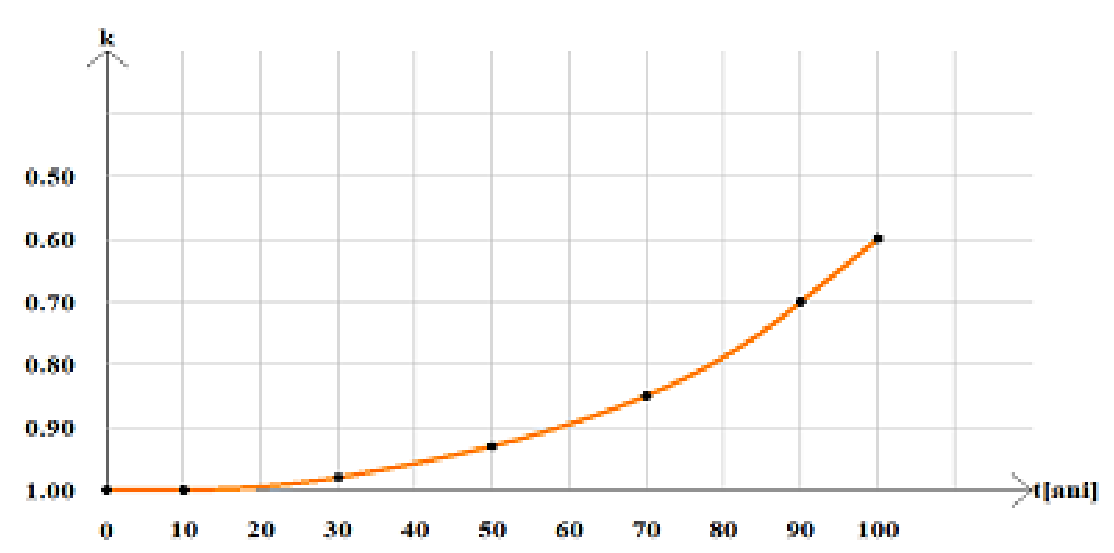

Figure 6: Change of coefficient ' $\mathrm{k}$ ' over time

The general structural facility condition index is the weighted average of the structural condition indices of the subunits (m), where ' $\mathrm{P}$ ' expresses the degree of structural role of the subunit as a percentage.

$$
\text { Ist }=\sum_{j=1}^{m} \mathrm{Pj} \text { Ist } \text { where } \quad \sum_{j=1}^{m} \mathrm{Pj}=1
$$

'Ist' the general consistency index calculation, where 'Ist' is the facility condition index or quality index calculated per subunit (according to the damage scores of the catalogues and tables given in the literature).

' $\mathrm{P}$ ' is the weighted ascertainment and determination of the subunits according to their role in the structure (value between 0 and 0.5 in general).

In our case study, the calculation of the general facility condition index of the Reformed Church of Aiton:

The study was carried out for 6 structural sub-assemblies, namely:

1) Foundation sub-assembly

2) Subassembly resistance walls

3) Sub-assembly of walled floors (charcoal bolts)

4) Wood floor sub-assembly

5) Wooden sander sub-assembly

6) Secondary structural sub-assemblies (partition walls, coverings, etc.)

Calculate quality indices on the above-mentioned sub-assemblies using the tables above.

1. Foundations

$1.1 \quad \mathrm{D}=0 \quad \mathrm{C} 1=10$

$1.2 \quad \mathrm{D}=0 \quad \mathrm{C}_{2}=10$

$1.3 \mathrm{D}=4 \quad \mathrm{C}_{3}=10-4=6$

movements at the foundation level.

$1.4 \quad \mathrm{D}=0 \quad \mathrm{C}_{4}=10$
No foundation shading and rotations.

No foundation shading and rotations.

The repeated flooding of the foundation ground over the years has caused

No injuries or fractures caused by the push of the earth were found. 
The Restoration of The Reformed Church of Aiton 2018-2020 Case Study, Condition Survey by Facility Condition Index

$1.5 \mathrm{D}=4 \quad \mathrm{C}_{5}=10-4=6 \quad$ Local cuts were found caused by material degradation (brick, connecting mortar) in the basement walls.

1.6 $\mathrm{D}=3 \mathrm{C}_{6}=10-3=7 \quad$ Faulty drainage installations caused moisture infiltrations into the walls, causing local degradation by falling mortar from joints and cracking masonry elements.

$1.7 \mathrm{D}=6 \mathrm{C}_{7}=10-4=6 \quad$ Local stone falls to the soles of masonry causing gangrene.

$1.8 \mathrm{D}=6 \mathrm{C}_{8}=10-4=6 \quad$ The destructive effect was high moisture through capillary in the walls, towards the vaults and higher towards the balcony.

$1.9 \mathrm{D}=0 \mathrm{C}_{9}=10$ No damage

$1.10 \mathrm{D}=0 \mathrm{C}_{10}=10$ No damage

Technical status index of the foundation sub-assembly according to the relationship:

Ist $=k \sum_{i=0}^{10} \mathrm{Ci}$

$I_{\text {stf }}=0.5 \times(10+10+6+10+6+7+6+6+10+10)=0.5 \times 81=40,5$,

(where $\mathrm{k}=0.5$ from times tab)

$P_{f}=0,2$ in the general technical state of the structure.

2. Loaded walls

$2.1 \mathrm{D}=2 \mathrm{C}_{1}=8$

$2.2 \mathrm{D}=3 \mathrm{C}_{2}=7$

Area plaster falls.

Damping to the walls due to lack of ventilation and water infiltrations in the absence of horizontal waterproofing.

$2.3 \mathrm{D}=3 \mathrm{C}_{3}=7$

Cracks in the walls, caused by Subsidence of foundations.

$2.4 \mathrm{D}=4 \mathrm{C}_{4}=6$

Cracks in the exterior walls due to a lack of upper belts at bridge level.

$2.5 \mathrm{D}=3 \mathrm{C}_{5}=7$ walls.

$2.6 \mathrm{D}=3 \mathrm{C}_{6}=7$ stiffening.

$2.7 \quad \mathrm{D}=0 \mathrm{C}_{7}=10$

$2.8 \mathrm{D}=0 \mathrm{C}_{8}=10$

Cracks in the corners due to lack of weaving between the longitudinal and transverse

$2.9 \mathrm{D}=0 \mathrm{C}_{9}=10$

Degradations of the walls above the wooden floors, caused by the lack of horizontal

$2.10 \mathrm{D}=0 \mathrm{C}_{10}=10$

$2.11 \mathrm{D}=0 \mathrm{C}_{11}=10$

$2.12 \mathrm{D}=0 \mathrm{C}_{12}=10$

No damage

No damage

No damage

No damage

No damage

No damage

$\mathrm{I}_{\text {stpr }}=0.5 \times(8+7+7+6+7+7+10+10+10+10)=0,5 \times 82=41$

with a share $P_{r w}=0,2$ in the general technical state of the structure.

3. Sub-assembly of walled floors

3.1. Wooden slabs

3.1.1 $\mathrm{D}=3 \quad \mathrm{C}_{1}=7 \quad$ Cracks caused by movements of the wall shoulders were found.

3.1.2 $\mathrm{D}=4 \quad \mathrm{C}_{2}=6 \quad$ Cracks caused by horizontal movements of the walls to their upper part were found, inclined to the vertical position.

3.1.3 $\quad \mathrm{D}=3 \quad \mathrm{C}_{3}=7 \quad$ There were overloads from the partition walls subsequently placed over the keystone keys, causing some cracks.

3.1.4 $\mathrm{D}=3 \quad \mathrm{C}_{4}=7 \quad$ There have been degradations of the walls due to flooding.

3.1.5 D $=0 \quad \mathrm{C}_{5}=10 \quad$ No previous interventions were found.

3.1.6 $\quad \mathrm{D}=0 \quad \mathrm{C}_{6}=10 \quad$ No previous interventions were found.

3.1.7 $\quad \mathrm{D}=4 \quad \mathrm{C}_{7}=6 \quad$ Flattening the vault swelled to the middle of opening it due to overloads from both temporary loads and successive layers of new floors executed without removing the previous bracket.

3.1.8 $\mathrm{D}=0 \quad \mathrm{C}_{8}=10 \quad$ No damage

3.1.9 $\mathrm{D}=0 \quad \mathrm{C}_{9}=10 \quad$ No damage

3.1.10 D = $0 \quad \mathrm{C}_{10}=10 \quad$ No damage

$\mathrm{I}_{\mathrm{stpz}}=0.5 \times(7+6+7+7+10+10+6+10+10+10)=82=41$ 
$\mathrm{P}_{\mathrm{pz}}=0,2$ in the general technical state of the structure.

3. 3 Wooden ceiling boards

3.3.1 $\mathrm{D}=7 \mathrm{C}_{1}=3 \quad$ The floor areas of adjoining wooden beams were attacked by anaerobic mushrooms.

3.3.2 D $=4 \quad \mathrm{C}_{2}=6 \quad$ Rotting ends of the floor beams were found, especially in eaves areas.

3.3.3 $\mathrm{D}=5 \quad \mathrm{C}_{3}=5 \quad$ The deformation of the arrow floors was found above those admitted in the middle of the openings, due to large permanent loads and insufficient stiffness of the floor beams.

3.3.4 D = $4 \quad C_{4}=6 \quad$ Wooden floorboards framed by wooden belts did not ensure sufficient stiffness for the transmission of horizontal loads to the walls.

$\begin{array}{llll}\text { 3.3.5 } & \mathrm{D}=0 & \mathrm{C}_{5}=10 & \text { No damage } \\ \text { 3.3.6 } & \mathrm{D}=0 & \mathrm{C}_{6}=10 & \text { No damage } \\ \text { 3.3.7 } & \mathrm{D}=0 & \mathrm{C}_{7}=10 & \text { No damage } \\ \text { 3.3.8 } & \mathrm{D}=0 & \mathrm{C}_{8}=10 & \text { No damage } \\ \text { 3.3.9 } & \mathrm{D}=0 & \mathrm{C}_{9}=10 & \text { No damage } \\ \text { 3.3.10 D }=0 & \mathrm{C}_{10}=10 & \text { No damage }\end{array}$

$\mathrm{I}_{\text {stpl }}=0.5 \times(3+6+5+6+10+10+10+10+10+10)=0,5 \times 84=40$

with a share of $\mathrm{P}_{\mathrm{pl}}=0,2$ in the general technical state of the structure.

3.4 Not sub-assemblies found

4. Wooden roofing

$4.1 \quad \mathrm{D}=7 \quad \mathrm{C}_{1}=3 \quad$ Degradation sought by the rotting of wood to most elements due to the penetration of rainwater through the degraded tile shell.

$4.2 \mathrm{D}=6 \quad \mathrm{C}_{2}=4 \quad$ The dislocated nodes, the spins, were produced by incorrect links and the rotting of wood from the end parts.

$4.3 \quad \mathrm{D}=5 \quad \mathrm{C}_{5}=5$

$4.4 \quad \mathrm{D}=0 \quad \mathrm{C}_{4}=10$ There was infestation with homemade fungus, on fairly large areas of the roof frame.

$4.5 \quad \mathrm{D}=0 \quad \mathrm{C}_{5}=10$ No damage

$4.6 \quad \mathrm{D}=0 \quad \mathrm{C}_{6}=10$ No damage

$4.7 \quad \mathrm{D}=0 \quad \mathrm{C}_{7}=10$ No damage

$4.8 \quad \mathrm{D}=0 \quad \mathrm{C}_{8}=10 \quad$ No damage

$4.9 \quad \mathrm{D}=0 \quad \mathrm{C}_{9}=10 \quad$ No damage

$4.10 \quad \mathrm{D}=0 \quad \mathrm{C}_{10}=10 \quad$ No damage

$\mathrm{I}_{\text {stş }}=0.5 \times(3+4+5+10+10+10+10+10+10+10)=0,5 \times 82=41$

with a share of $\mathrm{P}_{\text {şl }}=0,1$ in the general technical state of the structure.

5. Secondary sub-assemblies

$5.1 \quad \mathrm{D}=5 \quad \mathrm{C}_{1}=10-5=5$ Walls were found at the secondary entrance without proper foundations.

$5.2 \quad \mathrm{D}=4 \quad \mathrm{C}_{2}=10-4=6$ Tinkering mostly degraded.

$5.3 \quad \mathrm{D}=0 \quad \mathrm{C}_{3}=10$

$5.4 \quad \mathrm{D}=4 \quad \mathrm{C}_{4}=10-4=6$ The degradation of the masonry in the tower area required their demolition and reconstruction.

$5.5 \quad \mathrm{D}=4 \quad \mathrm{C}_{5}=6 \quad$ The wrapper was largely degraded, and was supplemented with several kinds of worn tile.
$5.6 \quad \mathrm{D}=5 \quad \mathrm{C}_{6}=5$
Part of the secondary walls were not only folded resulting in cracks in the corners.

$5.8 \mathrm{D}=4 \quad \mathrm{C}_{8}=6 \quad$ Gaps were found in the doors, with the original wooden frames left around the filling masonry, with no connection between them.

$5.9 \quad \mathrm{D}=0 \quad \mathrm{C}_{9}=10 \quad$ No damage

$\mathrm{I}_{\mathrm{sts}}=0.5 \times(5+6+10+6+6+5+5+6+10+10)=0,5 \times 69=34,5$

$\mathrm{P}_{\mathrm{ss}}=0,1$ in the general technical state of the structure.

$\mathrm{I}_{\mathrm{st}}=0,2 \times 40,5+0,2 \times 41+0,2 \times 41+0,2 \times 40+0,1 \times 41+0,1 \times 34,5=\mathbf{4 0 , 0 5}$

Here are the values of 'P' given by me: foundations $=0.2$, load-bearing walls $=0.2$, wooden slabs $=0.2$, wood ceiling $=0.2$, roofing $=0.1$, secondary sub. $=0.1$, etc. $\operatorname{SUM~P~}(1-6)=1$. 
The Restoration of The Reformed Church of Aiton 2018-2020 Case Study, Condition Survey by Facility Condition Index

Table 7: Walled Structural Condition Classes

\begin{tabular}{|c|c|c|c|}
\hline $\begin{array}{l}\text { Condition } \\
\text { class }\end{array}$ & $\begin{array}{l}\text { General } \\
\text { index } \\
\text { value }\end{array}$ & Findings and results after evaluation & Necessary, recommended interventions \\
\hline $\mathrm{I}$ & $80-100$ & Good state. Smaller damages, faults. & Local interventions. Conservations. \\
\hline II & $65-80$ & $\begin{array}{l}\text { Acceptable condition. Damages of various } \\
\text { nature and importance that do not } \\
\text { fundamentally affect the structural strength of } \\
\text { the construction. }\end{array}$ & Major repairs, local reinforcements. \\
\hline III & $50-65$ & $\begin{array}{l}\text { Unacceptable condition. } \\
\text { Damages of various sizes and types, which } \\
\text { already affect the durability of the structure or } \\
\text { substructure. }\end{array}$ & $\begin{array}{l}\text { Major repairs, local or greater } \\
\text { strengthening, general reconstruction. }\end{array}$ \\
\hline IV & $40-50$ & $\begin{array}{l}\text { Unacceptable condition. Subunits or structural } \\
\text { parts do not provide the required strength, } \\
\text { stability, static balance. }\end{array}$ & $\begin{array}{l}\text { General reinforcements (with partial } \\
\text { demolition and reconstruction), further } \\
\text { structural repairs. }\end{array}$ \\
\hline V & $30-40$ & $\begin{array}{l}\text { Unacceptable condition. Several structural } \\
\text { subunits do not meet the requirements for } \\
\text { durability, they do not provide the minimum } \\
\text { conditions of use. }\end{array}$ & $\begin{array}{l}\text { General structural reinforcements, } \\
\text { demolitions and reconstruction of several } \\
\text { local or complete subunits, and repair and } \\
\text { restoration of other supporting structures. }\end{array}$ \\
\hline VI & $<30$ & $\begin{array}{l}\text { Unacceptable condition. The general support } \\
\text { structure is not suitable for performing its static } \\
\text { and mechanical function. The damage is large } \\
\text { and widespread. The structure is unworthy of } \\
\text { renovation. }\end{array}$ & $\begin{array}{l}\text { In accordance with its historical value, } \\
\text { appropriate partial or complete } \\
\text { conservation techniques and solutions } \\
\text { must be determined. } \\
\text { Conservation of dilapidated state. }\end{array}$ \\
\hline
\end{tabular}

Classification based on facility condition index: According to Table 7 of the condition classes, the value of $\mathbf{4 0 . 0 5}$ corresponds to class IV. Intervention proposals for condition class IV: Structural reinforcements (foundations, walls), replacement of roof structure and roof covering, replacement of ceiling, general renovation.

\section{CURRENCY CONVERSION AND EVALUATION OF THE NUMBER OF THE FACILITY CONDITION INDEX "RV" IN THE CASE OF LISTED BUILDINGS. ALGORITHM DESIGN.}

\subsection{GROUPING OF MONUMENTAL BUILDINGS BY TYPE OF COMPARISON}

A, Secular buildings

- forts, castles

- mansions, mansion-like buildings

- palaces, palace buildings

- manor houses, estates

- administrative buildings, office buildings, banks, museums

- residential houses

$\mathrm{B}$, Denomination buildings

- cathedrals

- basilicas

- hall churches

- fortified churches

- chapels 
- tombstones, mausoleums

\subsection{CALCULATION OF COMPLEXITY FACTOR}

The complexity factor can be either Tc $=1,1.2$ or 1.5 , depending on the degree of decoration of the building. This can also be determined by the period of art history of the building (Romanesque, Gothic, Renaissance, Baroque and Rococo, eclectic, postmodern or Art Nouveau, Byzantine, Moorish, (Wallachian Renaissance), etc.).

\subsection{SURVEY OF STATISTICAL DATA}

Consideration and crediting of professionally executed, completed restorations, according to building types, separately.

\subsection{CHOOSE THE CHEAPEST AND MOST EXPENSIVE FROM THE RIGHT TYPE}

These are denoted by 'Vo' and 'Vd'.

\subsection{ADD INFLATION RATE}

Rin $=$ obtained from statistical data from the inflation table of the national, annual construction works.

\subsection{GF = SEVERITY FACTOR}

An exponential function of the value of damage between 0.01 and 100 . The values of the severity factor, based on the condition index table (Table 8), are as follows:

Monument Building Restoration Value: Rv

Table 8: Gf change in function of Ist

\begin{tabular}{|c|c|c|c|c|c|c|}
\hline & \multicolumn{7}{|c|}{ Gf, Severity factor } \\
\hline Class Ist & I80-100 & II 65-80 & III 50-65 & IV 40-50 & V30-40 & VI 0-30 \\
\hline Gf & $4-100$ & $2-4$ & $1-2$ & $0,7-1$ & $0,45-0,7$ & $0,01-0,45$ \\
\hline
\end{tabular}

In our case, the reference year is: 2016

$\mathrm{Vo}=220000 €, \mathrm{Vd}=692000 €, \mathrm{Tc}=1, \mathrm{Rin}=1.01, \mathrm{Gf}=1$

$\mathbf{R v}=(220.000+692.000) / 2 \times 1 \times(100-40.5) / 40.5 \times 1=669926 €$

This is the fastest and easiest estimate of the cost of restoring a listed building.

\section{SOURCES OF FUNDING}

None.

\section{CONFLICT OF INTEREST}

None. 


\title{
ACKNOWLEDGMENT
}

\author{
Condition Index
}

$\mathrm{S}$

The author express his gratitude to Prof. Dr. Ing. Bucur Horváth Ildikó for the warmth, patience and professional-academic competence with which her guided me throughout the years and urged me to specialized conferences and to publish scientific papers and communications related to the topic of rehabilitation of monuments.

\section{REFERENCES}

[1] Bucur Horváth, I., Bulbuk, M.: Original solutions for structural and functional rehabilitation of masonry buidings. Proceedings of the International Symposium on STUDIES ON HISTORICAL HERITAGE, Yildiz Tehnical University, Istanbul, Reserch Center for Preservation of Historical Heritage, TA-MIR, Antalya, Turkey, September 17-21, 2007, pp. 609-616, ISBN: 978-975-461-433-

[2] Bucur-Horváth, I., Popa, I., Bulbuk, M. \& Virág, J.: Historical Constructions - Authenticity and adaptation to the modern demands. Proceedings of the 6th International Conference on STRUCTURAL ANALYSIS of HISTORIC CONSTRUCTION, Volum 1, 2-4 July 2008, Bath, United Kingdom, pp. 169-174, CRC Press, Taylor an Francis Group, London, Balkema, ISBN Set978-0-415-46872-5.

[3] Márton István Bulbuk: Szerkezeti beavatkozások műemlék épületeknél. (Structural interventions on listed buildings.) Doctoral dissertation. Technical University of Cluj-Napoca, 2011. (Teza de doctorat, "Interventiistructurale la cladirimonumentale", U.T. Cluj-Napoca, 2011, in Romanian)3th June 2020, Budapest 